\title{
PENGARUH PEMBERIAN INFORMASI DAN DISKUSI TERSTRUKTUR PADA PERUBAHAN SIKAP KARYAWAN TERHADAP PENGGUNAAN ALAT PELINDUNG DIRI
}

\author{
Naomi Vembriati ${ }^{1}$, Supra Wimbarti ${ }^{2}$ \\ ${ }^{1)}$ Program Studi Psikologi Fakultas Kedokteran Universitas Udayana \\ Jl. Panglima Besar Sudirman, Denpasar \\ ${ }^{2)}$ Fakultas Psikologi Universitas Gadjah Mada \\ Jl. Humaniora no.1 Bulaksumur Yogyakarta \\ naomivembriati@gmail.com
}

\begin{abstract}
One of the factors causing high rates of workplace accidents is the human factor, i.e., the view that the use of Personal Protective Equipment (PPE) will cause the work discomfort and reduce the work speed so it will reduce the productivity. This attitude discourages employees to use PPE set by the company. This study was aimed to determine the effect of the provision of information and structured discussion on changes in employee attitudes towards the use of PPE. The design of experiment used in this research was multiple treatments and control with pretest, which involved two experimental groups and one control group. The first experimental group (EG1) was treated with the provision of information (academic detailing) and structured discussion. The second experimental group (EG2) received structured discussion without any provision of information. The control group (CG) was not given any treatment. The study involved 48 subjects, i.e. 16 people on EG1, 17 people on EG2, and 15 people in the CG. Statistical analysis using mixed ANOVA showed that there was a significant change in attitude towards the use of PPE $(\mathrm{F}=12.670 ; \mathrm{p}<0.001)$ lead to more negative attitude. The research also found that there were no differences in attitudes toward the use of PPE among groups $(\mathrm{F}=1.178 ; \mathrm{p}>0.05)$.
\end{abstract}

Keywords: academic detailing, structured discussion, attitude, personal protective equipment (PPE)

\begin{abstract}
Abstrak
Salah satu faktor penyebab tingginya angka kecelakaan kerja adalah faktor manusia, yaitu adanya pandangan bahwa penggunaan alat pelindung diri (APD) akan menimbulkan rasa tidak nyaman dalam bekerja dan menurunkan kecepatan saat bekerja sehingga dapat menurunkan produktivitas. Sikap ini mendorong karyawan untuk tidak menggunakan APD sebagaimana telah diatur oleh perusahaan. Penelitian ini bertujuan untuk mengetahui pengaruh pemberian informasi dan diskusi terstruktur pada perubahan sikap karyawan terhadap penggunaan APD. Rancangan eksperimen yang digunakan adalah multiple treatments and control with pretest, yaitu melibatkan dua kelompok eksperimen dan satu kelompok kontrol. Kelompok eksperimen pertama (KE1) mendapat perlakuan pemberian informasi (academic detailing) dan diskusi terstruktur. Kelompok eksperimen kedua (KE2) mendapat perlakuan diskusi terstruktur tanpa diberikan informasi. Kelompok kontrol tidak diberikan perlakuan apapun. Penelitian ini melibatkan 48 orang subjek, yaitu 16 orang pada KE1, 17 orang pada KE2, dan 15 orang pada KK. Hasil analisis statistik menggunakan anava campuran menunjukkan bahwa terjadi perubahan yang signifikan dalam sikap terhadap penggunaan APD $(F=12,670$; $p<0,001)$ menuju sikap yang semakin negatif. Selain itu, tidak terdapat pula perbedaan sikap yang signifikan antar kelompok $(\mathrm{F}=1,178$; $\mathrm{p}>0,05)$.
\end{abstract}

Kata kunci: academic detailing, diskusi terstruktur, sikap, alat pelindung diri (APD)

\section{PENDAHULUAN}

Kesehatan dan keselamatan kerja (K3) telah menjadi wacana yang penting dibicarakan dengan salah satu alasannya adalah tingginya tingkat kecelakaan kerja yang menyebabkan kerugian bagi organisasi. Sektor pertanian, pertam- 
bangan, konstruksi, dan transportasi dinyatakan sebagai industri dengan tingkat cidera dan kecelakaan fatal tertinggi bila dibandingkan dengan industri lain (Berry, 1998). Selain itu, Riyadina (2007) menyatakan bahwa perusahaan garmen menempati peringkat ketiga pada angka kecelakaan kerja, setelah perusahaan baja dan suku cadang.

Calvin dan Joseph (2006) menyatakan bahwa pada industri garmen, kecelakaan kerja sering terjadi, baik yang bersifat minor maupun mayor. Kecelakaan yang bersifat minor, antara lain jatuh, luka sayat dan memar, jari terjebak dalam mesin, dan luka akibat cipratan bahan kimia. Kecelakaan yang bersifat mayor atau mengakibatkan kecacatan permanen dan tidak dapat melaksanakan pekerjaan, bahkan meninggal dunia, seperti terjatuh dari ketinggian, luka potong akibat mesin pemotong, maupun kebakaran pabrik.

Jenis kecelakaan kerja yang paling sering terjadi pada perusahaan garmen adalah luka tusuk akibat jarum yang menusuk hingga ke tulang jari tangan, diikuti oleh luka sayat atau potong, luka akibat benda tumpul, luka bakar, dan masuknya benda asing ke dalam tubuh secara tidak sengaja (Calvin \& Joseph, 2006; Riyadina, 2007). Smith, Karsh, Carayon, dan Conway (2003) menyatakan bahwa karyawan pada industri garmen juga berpotensi menderita penyakit akibat kerja yang dipicu oleh terhirupnya debu hasil pemrosesan kain ke dalam saluran pernapasan, yang dikenal dengan istilah bisinosis (byssinosis).

Smith dkk. (2003) menyatakan adanya tiga kelompok intervensi dalam usaha mengontrol potensi bahaya di tempat kerja. Pertama, intervensi yang bertujuan menghilangkan potensi bahaya. Intervensi ini dapat dilakukan melalui redesain produk, alat, mesin, proses, maupun lingkungan menggunakan material yang tidak berbahaya atau memiliki potensi bahaya yang lebih kecil. Mesin-mesin yang digunakan pada industri garmen telah didesain ulang guna memasang peralatan keselamatan (safety equipment), seperti pemasangan polyguard maupun safety glass pada mesin jahit dan obras.

Kedua, intervensi yang bertujuan menutup akses karyawan terhadap potensi bahaya tersebut dengan membuat batasan sehingga karyawan tidak memasuki wilayah dengan potensi bahaya yang tinggi. Bila pembatasan wilayah ini tidak dimungkinkan, maka karyawan diharuskan untuk menggunakan alat pelindung diri atau APD (personal protection equipmentl PPE). Pada industri garmen terdapat beberapa macam APD, misalnya sarung tangan baja yang digunakan oleh karyawan di bagian pemotongan (cutting) dan juga masker yang akan melindungi karyawan dari debu kain pada saat pemrosesan. Penggunaan APD yang tersedia pada mesin dapat mencegah terjadinya kecelakaan tersebut (Calvin \& Joseph, 2006).

Ketiga, intervensi yang bertujuan memberikan peringatan kepada karyawan terkait dengan potensi bahaya dan melatih karyawan bagaimana cara untuk menghindari potensi bahaya tersebut. Bila intervensi kelompok pertama dan kedua bertujuan mengontrol faktor di luar individu, maka intervensi ketiga ini bertujuan untuk mengontrol faktor manusia yang berkontribusi pada terjadinya kecelakaan kerja. Intervensi ketiga ini penting dilakukan mengingat sering kali kecelakaan kerja terjadi dikarenakan faktor manusia, seperti saat karyawan mengabaikan prosedur keamanan yang berlaku.

Pengabaian prosedur kesehatan dan keselamatan kerja yang berlaku tampak dari perilaku mengabaikan pentingnya penggunaan APD dan peralatan keselamatan kerja. Hal ini terjadi pada 
banyak perusahaan di Indonesia, salah satunya terjadi pada karyawan dari PT. MAT, sebuah perusahaan yang bergerak dalam industri pakaian jadi. Berdasar wawancara yang dilakukan kepada Kepala Bagian Environment and Social Activities, yang bertanggung jawab melaksanakan berbagai kegiatan terkait kesehatan dan keselamatan kerja, terungkap adanya ketidakpatuhan karyawan dalam penggunaan APD yang ditetapkan oleh perusahaan. Karyawan akan menggunakan APD hanya pada saat dilaksanakan audit dalam rangka sertifikasi bagi fasilitas perusahaan. Selain itu, karyawan juga melakukan modifikasi terhadap peralatan keselamatan yang terpasang pada mesin.

Ketidakpatuhan karyawan PT. MAT ini terutama disebabkan oleh adanya anggapan karyawan bahwa penggunaan APD dan peralatan keselamatan kurang efektif, menimbulkan perasaan tidak nyaman dalam bekerja, serta mengurangi kecepatan dalam bekerja yang akhirnya menurunkan produktivitas kerja. Berbagai alasan tersebut menunjukkan adanya sikap negatif karyawan terhadap penggunaan APD yang mendorong karyawan berperilaku tidak aman dengan tidak menggunakan APD yang telah ditentukan. Hal ini senada dengan apa yang diungkapkan oleh Calvin dan Joseph (2006), bahwa kelalaian karyawan dalam menggunakan APD dipicu oleh ketidaknyamanan yang ditimbulkan saat bekerja menggunakan APD. Peneliti memandang bahwa sikap negatif ini menjadi salah satu permasalahan utama yang dihadapi oleh perusahaan dalam usaha meningkatkan kedisiplinan karyawan dalam menggunakan APD. Oleh karena itu, peneliti memilih sikap sebagai kriteria dalam penelitian ini dengan harapan saat sikap karyawan menjadi lebih positif terhadap penggunaan APD mereka akan dengan sukarela menggunakannya.
Sikap karyawan dalam suatu organisasi menjadi hal yang tidak dapat diabaikan keberadaannya karena akan mempengaruhi perilaku kerja karyawan (Robbins, 2005). Sikap dapat didefinisikan sebagai suatu pernyataan yang bersifat evaluatif, baik positif maupun negatif, terhadap objek tertentu (Olson \& Maio, 2003). Objek yang menjadi sasaran evaluasi individu dapat berupa objek apapun yang ada di lingkungan individu, termasuk sekelompok orang, berbagai isu kontroversial, maupun objek nyata lainnya.

Kristensen, Pedersen, dan Williams (2001) menyatakan tiga komponen dari sikap yang meliputi komponen kognisi, afeksi, dan konasi. Komponen kognitif adalah komponen yang menunjukkan pemikiran apakah suatu objek diinginkan atau tidak diinginkan. Komponen ini menunjukkan bagaimana seseorang berpikir mengenai suatu objek atau permasalahan. Komponen afektif adalah komponen yang menunjukkan adanya kontinum perasaan atau emosi dari suka hingga tidak suka mengenai objek atau permasalahan tertentu. Komponen konatif adalah komponen yang menggambarkan tindakan mendukung atau melawan suatu objek, situasi, maupun permasalahan tertentu.

Proses pembentukan sikap merupakan hasil evaluasi atas berbagai informasi terkait dengan ketiga komponen sikap. Proses yang pertama yaitu melalui proses kognitif. Olson dan Maio (2003) menyatakan bahwa salah satu sumber utama dari pembentukan sikap adalah informasi kognitif terkait dengan target sikap, yaitu kepercayaan terkait dengan atribut dari target tersebut. Pengetahuan mengenai target sikap dapat diperoleh melalui pengalaman langsung maupun tidak langsung. Pengalaman secara langsung terkait dengan target sikap cenderung menghasilkan sikap yang lebih kuat dibanding sikap yang dihasilkan atas 
dasar pengalaman tidak langsung. Proses kedua yaitu melalui proses afektif. Pada proses afektif, individu melakukan evaluasi terhadap target berdasar pada informasi mengenai perasaan yang ditimbulkan terkait dengan target sikap. Proses yang ketiga yaitu melalui proses perilaku, yaitu sikap individu terbentuk berdasar pada informasi mengenai tindakan yang telah dilakukan sebelumnya terkait dengan target sikap.

Olson dan Maio (2003) mengungkapkan bahwa proses psikologis yang terlibat dalam pembentukan sikap dapat pula mengarah pada perubahan sikap, yaitu perubahan sikap yang telah dimiliki individu menuju posisi evaluatif yang berbeda. Berdasar pada pemikiran ini, maka teori yang mendasari pembentukan sikap dapat pula dipakai sebagai pedoman dalam melakukan intervensi yang bertujuan untuk mengubah sikap individu. Basis informasi yang digunakan seseorang dalam melakukan evaluasi ini, baik informasi kognitif, afektif, maupun perilaku, memiliki implikasi yang penting dalam proses perubahan sikap (Petty, Wheeler, \& Tormala, 2003). Oleh karena itu, dalam melakukan intervensi perubahan sikap, penggunaan strategi yang disesuaikan dengan basis informasi yang digunakan individu dalam pembentukan sikap akan sangat menentukan keberhasilan intervensi tersebut.

Intervensi dalam mengubah sikap karyawan dapat dilakukan melalui berbagai cara, yaitu pelatihan, perlindungan, peningkatan kesadaran, pemberian insentif, investigasi kecelakaan, dan penggunaan APD (Adebiyi \& CharlesOwaba, 1990). Salah satu cara yang paling umum dilakukan adalah pelatihan karena berbagai penelitian telah membuktikan bahwa pelatihan dapat mempengaruhi keberhasilan dari program kesehatan dan keselamatan kerja (Adebiyi \& Charles-
Owaba, 1990). Tujuan dari aktivitas pencegahan kecelakaan berupa pelatihan adalah memberdayakan karyawan sehingga dapat mengenali adanya praktek maupun kondisi kerja yang tidak aman dan dapat menghindarinya secara mandiri. Melalui program pelatihan, karyawan dikenalkan pada faktor utama yang menyebabkan kecelakaan dan apa yang dapat ia lakukan untuk menghilangkan atau menghindarinya (Adebiyi \& CharlesOwaba, 1990). Melalui pelatihan dapat diberikan informasi yang dibutuhkan karyawan terkait dengan kesehatan dan keselamatan kerja. Pemberian informasi ini dapat dilakukan secara tertulis melalui brosur, spanduk, dan surat kabar perusahaan, maupun secara lisan melalui seminar atau pelatihan dengan tujuan mengubah sikap karyawan melalui proses kognitif.

Pemberian informasi ini telah dilakukan oleh Ewigman, Kivlahan, Hosokawa, dan Horman (1990) dalam bentuk seminar dan tanya jawab dan diikuti oleh masa percobaan penggunaan alat pelindung pendengaran pada para personil pemadam kebakaran di Missouri, Amerika Serikat. Informasi yang diberikan melalui pembagian handout meliputi empat hal, yaitu kebisingan dapat menyebabkan rusaknya pendengaran, paparan terhadap kebisingan merupakan hal yang banyak terjadi di lingkungan kerja subjek, berkurangnya pendengaran akan menyebabkan kecacatan yang tidak dapat disembuhkan, dan bahwa hilangnya pendengaran dapat dicegah. Selain itu, diberikan informasi melalui poster, rekaman penjelasan mengenai noiseinduced hearing lost (NIHL), booklet, rekaman wawancara terhadap personil pemadam kebakaran mengenai dampak hilangnya pendengaran terhadap kehidupan mereka. Intervensi yang diterapkan selama 3 bulan ini terbukti berhasil meningkatkan pengetahuan terkait dengan penyakit kehilangan pendengaran 
akibat kebisingan (NIHL), mendorong sikap yang lebih positif terhadap pencegahan NIHL dan penggunaan alat pelindung pendengaran, serta meningkatkan penggunaan alat pelindung pendengaran pada personil pemadam kebakaran.

Salah satu metode penyampaian informasi yang sering digunakan dalam dunia kedokteran adalah metode academic detailing atau sering pula disebut sebagai educational outreach. Pada awalnya, academic detailing merupakan metode yang digunakan oleh perwakilan dari perusahaan farmasi guna mempersuasi seorang dokter untuk meresepkan obat tertentu yang diproduksi oleh perusahaannya (Soumerai \& Avorn, dalam Mukti, Treloar, Wimbarti, Asdie, D’Este \& Higginbotham, 2000).

Panduan dalam pelaksanaan academic detailing meliputi (1) melaksanakan wawancara untuk mengetahui pengetahuan dan motivasi awal yang dimiliki, (2) membangun kredibilitas melalui dukungan dari organisasi terkemuka, (3) mengajukan nara sumber yang berwenang dan tidak bias, (4) mengemukakan permasalahan dari kedua sisi yang bertentangan, (5) menstimulasi partisipasi aktif dalam interaksi dua arah, (6) menggunakan material edukasi yang meyakinkan dan menarik perhatian secara visual, (7) mengulang dan memberikan penekanan pada pesan yang ingin disampaikan, dan (8) memberikan reinforcement positif dari adanya perubahan menuju perilaku yang diharapkan (Soumerai \& Avorn, 1990; Simon, Smith, Feldstein, Perrin, Yang, Zhou, Platt, \& Soumerai, 2006).

Mukti, dkk. (2000) menyatakan bahwa saat ini telah dilakukan penelitian terkait dengan academic detailing sebagai suatu strategi pencegahan guna mengubah perilaku berisiko dari para pekerja di bidang kesehatan. Treloar, Higginbotham, Malcolm, Sutherland, \& Berenger (1996) membuktikan bahwa academic detailing berhasil meningkatkan kepatuhan pekerja kesehatan terhadap panduan yang berlaku dalam situasi klinis maupun saat terjadi praktek kerja yang tidak aman.

Stave, Törner, dan Eklőf (2007) dalam penelitiannya pada petani di Swedia membandingkan tiga pendekatan intervensi, yaitu pendekatan terbuka, pendekatan terstruktur, dan pendekatan terstruktur yang disertai pemberian informasi guna meningkatkan aktivitas terkait keselamatan dan persepsi akan kemungkinan mengelola risiko, serta menurunkan stres kerja, persepsi akan risiko, dan penerimaan terhadap risiko. Pada pendekatan terbuka, diskusi yang dilakukan bersifat bebas namun tetap fokus pada resiko, keselamatan, dan faktor-faktor yang mempengaruhinya.

Kelompok dengan pendekatan terstruktur menggunakan cara analisis yang lebih terstruktur terkait dengan kejadian/ kecelakaan kelompok, yaitu melalui serangkaian pertanyaan. Pertanyaan yang diajukan pada anggota kelompok ini meliputi waktu kejadian, tipe cidera yang dialami, bagaimana kecelakaan dapat terjadi, kejadian apa yang mendahului kecelakaan, penyebab kecelakaan menurut anggota kelompok, bagaimana cidera dapat dihindari saat kecelakaan tidak menyebabkan orang terluka, dan bagaimana kejadian/kecelakaan serupa dapat dicegah di masa yang akan datang. Kelompok ini menggunakan bantuan buku harian yang diberikan pada setiap anggota sebagai media mendokumentasikan dan menelusuri penyebab dari kejadian/kecelakaan.

Kelompok ketiga menggunakan pendekatan terstruktur disertai pemberian informasi yang bertujuan sebagai cara meningkatkan kesadaran akan resiko dan 
konsekuensi negatif yang menyertainya. Informasi yang diberikan meliputi tingkat kecelakaan dalam sektor pertanian, tipe dan efek kecelakaan, analisa biaya terkait dengan kecelakaan, sikap yang umum ditunjukkan terhadap sumber resiko, dan sikap yang ditunjukkan petani pada umumnya terkait dengan resiko dan keselamatan. Hasil penelitian menunjukkan bahwa ketiga intervensi berhasil meningkatkan aktivitas terkait dengan kesehatan dan keselamatan kerja serta menurunkan stres kerja dan penerimaan risiko dengan perubahan yang paling baik ditunjukkan oleh kelompok dengan pendekatan terstruktur, baik yang disertai dengan pemberian informasi, maupun tanpa pemberian informasi.

Stave (2005) menyatakan bahwa penggunaan pendekatan terstruktur dalam analisis rekonstruksi kecelakaan bertujuan membantu partisipan untuk mengungkap faktor-faktor resiko yang tertanam dalam praktek kerja sehari-hari sehingga partisipan dapat meningkatkan kesadaran karyawan atas situasi kerja dan faktorfaktor risiko yang berkontribusi pada terjadinya kecelakaan kerja (risk awareness). Semakin tinggi kesadaran karyawan akan risiko yang dihadapinya diharapkan akan meningkatkan kesadaran karyawan akan pentingnya penggunaan APD sehingga dapat mengubah sikap karyawan menjadi lebih positif terhadap kebijakan penggunaan APD selama bekerja.

Penelitian Stave Törner, dan Eklőf (2007) telah membuktikan efek dari analisis terstruktur yang terlihat dari adanya perubahan pemahaman partisipan. Selain itu, dua pertiga subjek menyatakan bahwa penggunaan buku harian sebagai lembar kerja bermanfaat bagi mereka dan mengindikasikan bahwa cara analisis yang terstruktur terhadap kecelakaan/kejadian yang terjadi dapat mempengaruhi pan- dangan mereka atas risiko yang mereka hadapi di tempat kerja. Perubahan pandangan atas risiko ini diharapkan akan mendorong karyawan untuk terlibat lebih jauh dalam program kesehatan dan keselamatan kerja di tempat kerja, termasuk juga mematuhi aturan dan prosedur yang ditetapkan dalam perusahaan, seperti penggunaan APD saat bekerja.

Pengungkapan kejadian kecelakaan kerja oleh karyawan yang mengalaminya, atau dikenal sebagai testimoni, dinyatakan lebih berguna dibanding penggunaan angkaangka hasil analisis statistik dalam meningkatkan kesadaran akan risiko dan memotivasi munculnya perilaku aman dalam bekerja (Geller, 2001). Testimoni juga terbukti berhasil mengubah sikap personil pemadam kebakaran terhadap penggunaan alat pelindung pendengaran, yaitu menggunakan rekaman hasil wawancara terhadap pemadam kebakaran yang mengalami NIHL mengenai dampak hilangnya pendengaran terhadap kehidupan mereka (Ewigman, dkk., 1990). Refleksi yang dikomunikasikan secara terbuka dapat mendukung adanya proses pembelajaran dari sesama.

Sistem pembelajaran kooperatif (cooperative learning) adalah strategi pembelajaran dimana pelajar bekerja dalam kelompok kecil untuk meraih satu tujuan bersama (Omrod, 2003). Pembelajaran kooperatif berbeda dengan sekelompok pelajar yang mengerjakan tugas bersama. Pendekatan pembelajaran kooperatif memiliki bebe-rapa fitur utama, antara lain pelajar bekerja dalam kelompok kecil yang dibentuk oleh pengajar, kelompok memiliki satu atau lebih tujuan bersama yang akan diraih, pelajar diberikan panduan yang jelas terkait bagaimana mereka harus bersikap, sebuah struktur diberikan untuk meng-giring perilaku belajar yang produktif, pengajar 
berperan sebagai pengawas (Omrod, 2003).

Penjelasan di atas mengarah pada asumsi bahwa pemberian informasi melalui academic detailing dan diskusi terstruktur dalam analisis kecelakaan kerja dapat mengubah sikap karyawan. Penelitian ini bertujuan menguji pengaruh intervensi pemberian informasi dan diskusi terstruktur dalam mengubah sikap karyawan terhadap penggunaan APD.

Hipotesis penelitian ini adalah, pemberian informasi dan diskusi terstruktur mengenai kecelakaan kerja yang pernah dialami dapat mengubah sikap karyawan menjadi lebih positif terhadap penggunaan APD. Pemberian informasi dan diskusi terstruktur secara bersama akan mengubah sikap karyawan terhadap penggunaan APD, lebih positif dibanding hanya melalui diskusi terstruktur saja.

\section{METODE}

Subjek penelitian ini adalah karyawan PT. MAT dari bagian produksi yang mewakili setiap bagian sesuai dengan proses bisnis yang ada, yaitu bagian pemotongan (cutting), jahit (sewing), dan finishing. Pemilihan subjek dilakukan dengan prinsip stratified sampling, yaitu membagi populasi menjadi beberapa strata sehingga pada setiap strata tercapai homogenitas dan diperoleh sampel yang dapat mewakili strata yang ada pada populasi. Terdapat dua strata yang digunakan dalam penelitian ini. Strata pertama adalah karyawan yang pernah mengalami atau terlibat dalam suatu kecelakaan di tempat kerja. Strata kedua adalah karyawan yang belum pernah mengalami kecelakaan kerja.

Pendekatan yang digunakan peneliti adalah stratifikasi tidak proporsional (disproportional stratified sampling), yaitu pengambilan sampel ke dalam strata tidak disesuaikan dengan proporsi dalam populasi namun berdasar penentuan proporsi dalam sampel.

Subjek penelitian dibagi dalam tiga kelompok, yaitu dua kelompok eksperimen (KE1 dan KE2) dan satu kelompok kontrol (KK) dengan masing-masing kelompok terdiri atas 20 orang, terdiri atas 10 orang dari strata pertama dan 10 orang dari strata kedua. Khusus bagi KK, subjek dipilih dari karyawan pada bagian pembuatan sampel. Hal ini dilakukan sebagai usaha untuk menyiasati adanya ancaman terhadap validitas internal, khususnya kemungkinan akan kontaminasi efek dari perlakuan yang diberikan karena adanya komunikasi antarkelompok atau diffusion or imitation of treatments (Cook \& Campbell, 1979; Schweiger \& DeNisi, 1991). Bagian sampel dipilih sebagai KK karena memiliki tempat kerja yang terpisah dari bagian produksi sehingga dapat meminimalisasi kemungkinan subjek KK berkomunikasi mengenai kegiatan yang dilakukan KE terkait dengan penelitian ini.

Penentuan subjek ke dalam masing-masing kelompok dilakukan dengan cara random (random assignment). Proses ini dimulai dengan meminta daftar karyawan yang diberi izin untuk mengikuti kegiatan penelitian ini. Adanya keterbatasan jumlah karyawan yang pernah mengalami kecelakaan di tempat kerja menyebabkan semua karyawan yang pernah mengalami kecelakaan dilibatkan dalam penelitian ini, baik pada bagian sampel maupun produksi. Randomisasi dilakukan untuk memasukkan karyawan pada KE1 dan KE2. Subjek pada KK dipilih oleh pihak perusahaan. Pada hari pelaksanaan penelitian empat orang subjek tidak hadir, yaitu dua orang subjek dari KE1 dan dua orang subjek dari KE2, maka keempat subjek ini tidak diikutsertakan dalam analisis selanjutnya. 
Variabel dependen dalam penelitian ini adalah sikap karyawan terhadap penggunaan alat pelindung diri (APD). Pengukuran atas variabel ini dilakukan menggunakan Skala Sikap Penggunaan APD yang terdiri atas 42 aitem $(\alpha=0,94)$. Skala ini dibuat berdasarkan pernyataan Kristensen, Pedersen, dan Williams (2001) dalam penelitiannya mengenai sikap yang terdiri atas tiga komponen, yaitu kognisi, afeksi, dan konasi. Setiap aitem memiliki 4 pilihan jawaban yang bergerak antara 1 (sangat tidak setuju) sampai dengan 4 (sangat setuju). Pada aitem unfavorable diskor secara terbalik, yaitu skor 1 (sangat setuju) sampai dengan 4 (sangat tidak setuju). Skor total sikap terhadap pengunaan APD diperoleh dengan menjumlahkan skor dari setiap aitem dari skala tersebut. Semakin tinggi skor total yang diperoleh subjek menunjukkan semakin positif sikapnya terhadap penggunaan APD.

Pada penelitian ini diberikan dua bentuk intervensi, yaitu pemberian informasi dan diskusi terstruktur mengenai kecelakaan di tempat kerja. Intervensi pertama, pemberian informasi, dilakukan dengan mengadaptasi prinsip dari academic detailing, yaitu suatu strategi pencegahan guna mengubah perilaku beresiko (Mukti, dkk., 2000). Pemberian informasi dilakukan dengan metode ceramah selama 45 menit. Informasi yang diberikan dalam intervensi ini meliputi resiko kerja di perusahaan garmen, baik berupa penyakit akibat kerja maupun kecelakaan kerja. Setiap resiko dijelaskan satu-persatu berikut dengan alat perlindungan yang dapat digunakan untuk menghindari penyakit maupun kecelakaan yang mungkin terjadi. Pada diskusi terstruktur subjek diminta untuk berbagi cerita tentang pengalaman terkait dengan kecelakaan yang pernah dialaminya di tempat kerja.
Diskusi terstruktur dilakukan dengan metode Focus Group Discussion (FGD) selama kurang lebih 60 menit dan didampingi oleh satu orang fasilitator dan satu orang pengamat pada setiap kelompok kecil. Subjek yang pernah mengalami kecelakaan kerja diminta menganalisis kecelakaan tersebut dengan mengikuti panduan yang diberikan oleh fasilitator. Subjek yang belum pernah mengalami kecelakaan juga diberikan kesempatan untuk menceritakan pengalaman mereka menyaksikan kecelakaan dari rekan kerja mereka dan juga berbagi cara kerja yang sekiranya dapat menghindarkan mereka dari kecelakaan kerja. Giliran untuk berbicara diberikan secara bergantian dan masing-masing anggota kelompok memiliki kesempatan untuk berbicara. Diskusi dilaksanakan secara bebas namun tetap fokus pada topik terkait dengan risiko, kesehatan dan keselamatan kerja, dan faktor-faktor yang mempengaruhinya.

Diskusi terstruktur dilaksanakan sesuai dengan fitur dari pembelajaran kooperatif. Pertama, subjek dari KE1 dan KE2 akan dibagi ke dalam kelompok kecil pada saat pelaksanaan diskusi yang penetapannya dilakukan oleh peneliti. Pada pelaksanaan intervensi, subjek dibagi lagi ke dalam kelompok-kelompok kecil yang terdiri atas lima sampai enam orang. Hal ini dilakukan sesuai dengan prinsip dalam pembelajaran kooperatif yang berjalan efektif bila dilakukan dalam kelompok kecil (Omrod, 2003). Setiap kelompok kecil ini mendapatkan perlakuan yang sama sesuai dengan keanggotaannya dalam kelompok eksperimen. Pembagian subjek dalam kelompok kecil dilakukan secara acak menggunakan undian dengan tetap mempertahankan proporsi dari kedua strata, yaitu subjek yang pernah mengalami kecelakaan kerja dan subjek yang belum pernah mengalaminya. 
Kedua, kelompok memiliki tujuan bersama, yaitu memberi kesempatan pada subjek untuk berbagi pengalaman kecelakaan kerja dan bersama-sama menemukan faktor penyebabnya untuk kemudian menentukan langkah pencegahan. Ketiga, pada awal kegiatan diskusi disampaikan pada subjek mengenai code of conduct yang berlaku selama proses diskusi berjalan. Keempat, subjek diberikan panduan dalam melakukan analisis kecelakaan kerja yang pernah dialami melalui lembar kerja yang diberikan saat diskusi dimulai. Tujuan dari penggunaan lembar kerja ini adalah menyediakan contoh kejadian berbahaya yang nyata dan telah dialami sendiri oleh partisipan sebagai awal yang baik bagi refleksi dan mempromosikan sebuah cara baru untuk memahami suatu kecelakaan dengan mengikuti kejadian sampai pada hulu, merefleksikan kondisi, prasyarat, dan perilaku. Kelima, pengajar atau dalam penelitian ini disebut sebagai fasilitator berperan untuk memastikan bahwa interaksi dalam kelompok berjalan produktif.

Rancangan eksperimen yang digunakan adalah perlakuan ganda dengan kelompok kontrol dan pemberian tes pendahuluan (Multiple treatments and control with pretest), yaitu rancangan ekperimen yang menggunakan pretest dan proses randomisasi serta melibatkan adanya sebuah kelompok kontrol dan lebih dari satu kelompok eksperimen (Shadish, Cook, \& Campbell, 2002).

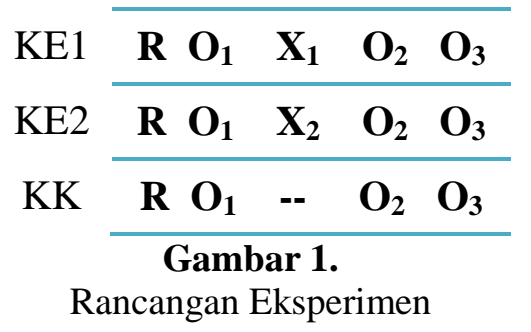

Kelompok eksperimen pertama (KE1) menerima intervensi berupa pemberian informasi (academic detailing) yang diikuti dengan diskusi terstruktur mengenai analisis reflektif dari kecelakaan kerja. Kelompok eksperimen kedua (KE2) menerima intervensi berupa diskusi terstruktur mengenai analisis reflektif kecelakaan kerja tanpa disertai pemberian informasi. Kelompok kontrol (KK) tidak menerima perlakuan apapun.

Pada penelitian ini ditambahkan pula pengukuran ketiga (O3/ follow up), yaitu pengukuran kedua paska penelitian. Hal ini dilakukan supaya peneliti dapat memastikan apakah efek perlakuan berlaku selama durasi waktu tertentu yang signifikan atau dengan cepat kembali pada kondisi semula (Shadish, Cook, \& Campbell, 2002). Peneliti menggunakan posttest berganda dengan pertimbangan bahwa efek perlakuan yang perlu dipastikan bukan hanya yang berfokus pada perubahan perilaku, namun juga meliputi perubahan dalam hal sikap subjek. Selain itu, Shadish, dkk. (2002) juga menyatakan bahwa penggunaan posttest berganda sangat membantu peneliti dalam melakukan interpretasi dari hasil penelitian kuasi-eksperimen.

Data dalam penelitian ini dianalisis dengan menggunakan teknik analisis data anava campuran (Diekhoff, 1992), karena rancangan analisis ini memuat pengamatan berulang yaitu pra dan pasca pelatihan dengan dua kelompok penelitian yaitu KE1 dan KE2, serta satu KK. Pengukuran dengan anava campuran dilakukan untuk mengukur sikap karyawan terhadap penggunaan APD pra dan pasca intervensi pemberian informasi dan diskusi terstruktur, serta melihat perubahan sikap karyawan terhadap penggunaan APD pada KE1 dan KE2, serta pada KK. Sebagai pendukung dari analisis kuantitatif, dilakukan pula analisis kualitatif terhadap data hasil rekaman kegiatan diskusi dari masing-masing kelompok. 


\section{HASIL DAN PEMBAHASAN}

Hasil analisis deskriptif menunjukkan bahwa pada pengukuran pra dan paska intervensi yang pertama terjadi penurunan rerata sikap terhadap penggunaan APD pada semua kelompok. Hal ini berarti terjadi perubahan sikap subjek terhadap penggunaan APD, dari sikap yang positif berubah menjadi lebih negatif. Pada pengukuran paska intervensi yang kedua terjadi peningkatan rerata sikap terhadap penggunaan APD pada KE1 dan KE2 dan penurunan pada KK. Hal ini berarti terjadi perubahan sikap pada subjek KE1 dan KE2 menjadi lebih positif terhadap penggunaan APD dan pada subjek KK perubahan menjadi semakin negatif.

Uji normalitas menunjukkan bahwa sebaran data dapat dinyatakan normal. Uji homogenitas menunjukkan sebaran data yang diperoleh homogen atau tidak ada perbedaan data kelompok yang signifikan satu sama lain.

Peneliti menggunakan analisis varian campuran untuk mendapatkan hasil pengujian perbedaan skor antarkelompok (KE1, KE2, KK) dan pengujian perbedaan skor dalam satu kelompok (pretest, posttest, follow up). Hasil analisis menunjukkan adanya perubahan yang signifikan dalam sikap karyawan terhadap penggunaan APD. Namun, perubahan yang terjadi mengarah pada sikap yang semakin negatif terhadap penggunaan APD. Hal ini berkebalikan dengan hipotesis yang diajukan dalam penelitian ini.

Analisis statistik juga menunjukkan bahwa subjek mengalami perubahan sikap yang signifikan terhadap penggunaan APD dari pengukuran pertama menuju pengukuran kedua. Perubahan ini mengarah pada sikap yang lebih negatif dibanding pada saat belum dilakukan intervensi. Pada pengukuran ketiga, perubahan sikap yang muncul tidaklah signifikan. Perubahan yang terjadi pada masing-masing kelompok tidak menunjukkan perbedaan yang signifikan antara KE1, KE2, maupun KK.

Sebagai tambahan, dilakukan analisis secara kualitatif terhadap proses diskusi terstruktur yang dilakukan dalam kelompok-kelompok kecil. Proses perekaman dilakukan setelah mendapat persetujuan dari subjek yang terlibat dalam diskusi. Analisis dilakukan pada level kelompok, bukan pada level individu.

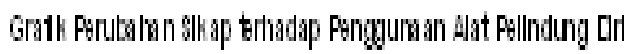

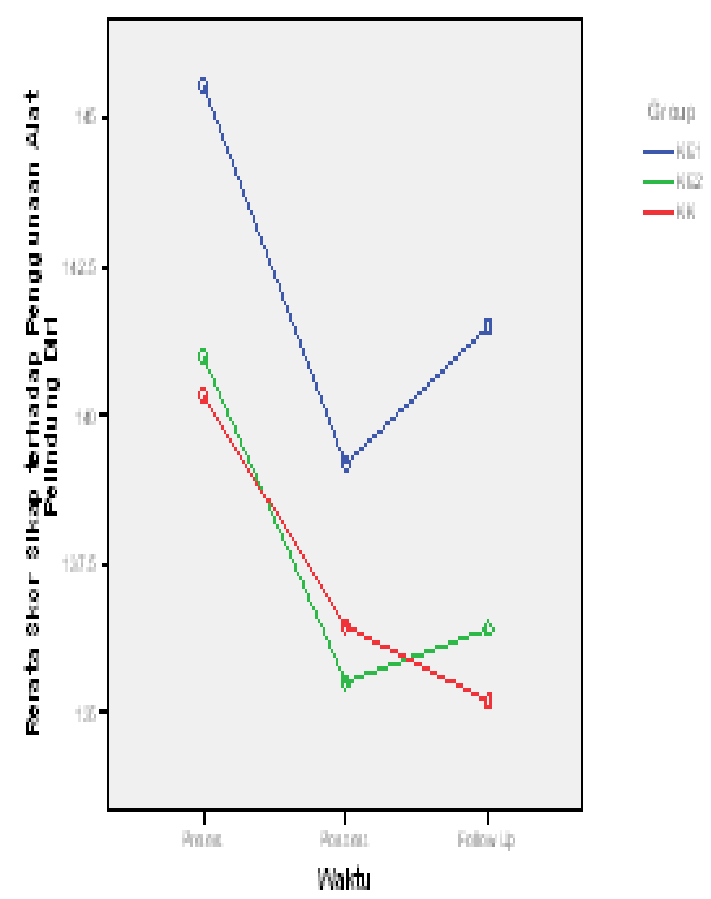

Gambar 2.

Grafik Perubahan Sikap Karyawan terhadap Penggunaan APD

Beberapa kesimpulan dapat diambil dari analisis data kualitatif. Kesimpulan pertama terkait dengan kecelakaan kerja terjadi di PT. MAT. Kecelakaan kerja yang paling sering terjadi di PT. MAT adalah tertusuk jarum jahit. Bahkan terungkap pula bahwa dalam satu hari terjadi lebih dari satu kejadian kecelakaan kerja 
tertusuk jarum jahit dengan tingkat keparahan yang berbeda-beda. Kecelakaan lain yang sering pula terjadi adalah kecelakaan di bagian pemotongan, baik melibatkan mesin cutter yang besar maupun gunting. Pada salah satu kejadian, kaki seorang karyawan terkena mesin cutter karena posisi kerja yang tidak sesuai aturan, yaitu melakukan pemotongan kain dengan berjongkok di atas tumpukan kain. Hal ini dilakukan karena keterbatasan kondisi fisik karyawan yang bertubuh kecil sehingga tidak dapat melakukan pemotongan kain secara maksimal bila dilakukan dengan posisi kerja yang ditetapkan, yaitu berdiri di samping meja pemotongan. Kecelakaan lain yang terjadi dengan frekuensi rendah misalnya luka bakar pada kulit tangan akibat terjepit dalam mesin press, jari yang terjepit mesin jahit, kaki terlindas mesin troli, tangan terjepit mesin pemasang kancing, tangan terbakar akibat terkena mesin pelicin pakaian, tangan terkena mesin jahot obras/ kelim, kaki yang kejatuhan pemberat kain, kaki terkena paku pada kayu yang tergeletak di kamar mandi, maupun terpeleset di kamar mandi.

Kesimpulan kedua adalah waktu kecelakaan terjadi. Kecelakaan kerja ini umumnya terjadi menjelang waktu istirahat siang, pada waktu setelah istirahat siang (pukul 2-3 siang), maupun menjelang selesainya jam kerja.

Kesimpulan ketiga adalah faktor penyebab kecelakaan. Pada diskusi terungkap bahwa penyebab dari kecelakaan kerja umumnya adalah karyawan bekerja dalam kondisi mengantuk, kelelahan, kurang konsentrasi, dan tergesa-gesa karena mengejar target pengiriman barang. Selain itu, juga terungkap faktor penyebab lain, seperti tidak terbiasa menggunakan mesin yang bersangkutan atau kurangnya pengalaman kerja, karyawan bekerja dengan posisi kerja yang tidak sesuai aturan, ketiadaan alat pengaman pada mesin (needle guard dan pengaman mesin saat dibersihkan), alat kerja tidak dalam kondisi yang baik (roda troli yang seret), serta penempatan alat yang tidak aman.

Kesimpulan keempat adalah tindakan pencegahan terhadap kecelakaan. Hasil dari diskusi mengungkap bahwa tindakan pencegahan yang telah dilakukan adalah bekerja dengan lebih hati-hati dan lebih berkonsentrasi. Penggunaan APD dipandang tidak efektif dalam mencegah terjadinya kecelakaan. Di samping keberadaannya yang sering dianggap mengganggu dan memperlambat dalam bekerja, APD juga sering dikesampingkan penggunaannya dengan alasan merusak kain yang sedang dijahit.

Sistem kerja yang diterapkan pada PT. MAT menggunakan sistem line, dimana karyawan secara berkelompok mengerjakan tugas yang telah ditentukan untuk kelompok tersebut. Misalnya pada bagian jahit, karyawan bekerja dalam 1 line untuk mengerjakan penjahitan mulai dari bentuk potongan kain hingga menjadi satu pakaian yang utuh. Setiap anggota line mengerjakan jahitan yang berbeda secara berantai dari belakang ke depan sesuai dengan keterampilan yang dimiliki. Semakin ke depan, pekerjaan jahit semakin sulit dan rumit. Anggota paling depan adalah karyawan yang dianggap paling mahir dalam menjahit, sedangkan anggota paling belakang biasanya adalah karyawan baru yang belum banyak memiliki pengalaman dalam menjahit. Bila ada satu anggota yang tidak hadir maka pekerjaan dalam 1 line akan terhambat. Hal ini menyebabkan karyawan cenderung melakukan kegiatannya dengan tergesa-gesa untuk menghindari protes dari rekan kerja 1 line maupun pengawas akibat menghambat pekerjaan. Ketidakhadiran karyawan karena cuti harus ditanggung bersama oleh rekan 1 line dengan bekerja ganda, 
mengerjakan apa yang seharusnya dikerjakan oleh anggota yang tidak masuk tersebut. Sistem kerja berorientasi hasil yang diterapkan oleh PT. MAT menuntut karyawan untuk bekerja dengan kecepatan tinggi dalam waktu lama (bahkan lembur hingga pukul 12.00 tengah malam) guna mengejar pemenuhan target. Hal ini diduga menjadi salah satu penyebab terjadinya kecelakaan kerja. Kondisi ini diperparah oleh keadaan karyawan yang lelah dan mengantuk setelah seharian bekerja maupun telah lembur pada hari sebelumnya.

Calvin dan Joseph (2006); Riyadina (2007); dan Smith, Karsh, Carayon, dan Conway (2003) menyatakan bahwa karyawan yang bekerja pada industri garmen menghadapi berbagai resiko, baik yang berupa penyakit akibat kerja maupun kecelakaan kerja. Besarnya resiko penyakit dan kecelakaan kerja yang dihadapi ini diperparah dengan perilaku kerja tidak aman yang dipraktekkan oleh karyawan PT. MAT. Hal ini tampak dari hasil observasi dan wawancara dengan pihak perusahaan sebelum penelitian dilaksanakan yang menunjukkan bahwa karyawan tertib menggunakan APD terutama saat dilakukan audit maupun saat pihak pembeli datang melakukan inspeksi. Perilaku karyawan tidak menggunakan APD ini dipicu adanya pandangan yang negatif terhadap penggunaan APD, yaitu membuat dirinya bekerja kurang cepat, APD dipandang kurang efektif, dan menimbulkan ketidaknyamanan dalam bekerja. Intervensi berupa academic detailing dan diskusi terstruktur dilaksanakan dengan tujuan mengubah sikap karyawan terhadap penggunaan APD sehingga nantinya memiliki sikap positif yang pada gilirannya akan mendorong karyawan untuk menunjukkan perilaku disiplin dalam menggunakan APD yang telah ditentukan oleh perusahaan.
Hasil analisis kuantitatif menunjukkan bahwa terdapat perubahan sikap yang signifikan dalam sikap karyawan terhadap penggunaan APD, namun perubahan ini memiliki nilai berkebalikan dengan hipotesis yang disampaikan oleh peneliti. Selain itu, hasil analisis juga menunjukkan bahwa tidak terdapat perbedaan atas perubahan sikap terhadap penggunaan APD, antara KE1, KE2, maupun KK. Hal ini menunjukkan bahwa intervensi yang diberikan, baik pemberian informasi berupa academic detailing dan diskusi terstruktur secara berurutan, maupun diskusi terstruktur saja, tidak menunjukkan pengaruh yang berbeda pada kedua kelompok eksperimen. Hasil ini bertentangan dengan hasil penelitian yang dilakukan oleh Mukti, dkk. (2000) mengenai academic detailing, Stave, Tőrner, dan Eklőf (2007) mengenai diskusi terstruktur, serta Geller, (2001) dan Ewigman, dkk. (1990) mengenai efektivitas testimoni dalam mengubah sikap.

Perubahan sikap dengan arah yang berkebalikan menggambarkan sikap karyawan yang semakin negatif terhadap penggunaan APD. Kecenderungan berubahnya sikap menjadi semakin negatif bukan hanya tampak pada kelompok eksperimen, namun juga pada kelompok kontrol meskipun perubahannya tidak signifikan secara statistik. Hal ini diduga terkait dengan iklim kerja perusahaan yang tidak menempatkan kesehatan dan keselamatan kerja sebagai prioritas melebihi target produksi. Saat bekerja, karyawan sering dihadapkan pada konflik dalam memilih apakah akan bekerja dengan aman atau bekerja dengan cepat. Sistem kerja yang berorientasi hasil yang diterapkan oleh manajemen PT. MAT sebagaimana dijelaskan sebelumnya akan berdampak negatif pada berbagai usaha promosi terkait kesehatan dan keselamatan kerja. 
Perusahaan menempatkan nilai produktivitas di atas nilai kesehatan dan keselamatan kerja sehingga karyawan akan lebih fokus pada usaha memenuhi target produksi dibanding bekerja secara aman. Bahkan secara terang-terangan perusahaan sering mengesampingkan aturan dalam keselamatan kerja demi tercapainya target produksi dalam batas waktu yang telah ditentukan. Pada diskusi terungkap bahwa karyawan, atas sepengetahuan atasannya, dengan sengaja mengalihkan needle guard dari posisi yang semestinya supaya dapat bekerja dengan lebih cepat. Hal ini dilakukan dengan alasan penggunaan needle guard dipandang sebagai penghalang dalam melakukan pekerjaan karena karyawan harus bekerja lebih lambat saat bekerja supaya needle guard tidak sampai merusak kain yang akan dijahit. Selain itu, perusahaan juga tidak menerapkan aturan keselamatan kerja dengan baik. Pada diskusi terungkap bahwa sebagian karyawan mengalami kecelakaan kerja pada saat ia bekerja tidak sesuai standar yang berlaku.

Slappendal, Laird, Kawachi, Marshall, dan Cryer (dalam Barling \& Frone, 2004) menyatakan bahwa perilaku kerja yang tidak aman cenderung akan dipersepsi lebih menguntungkan bila hal tersebut memungkinkan karyawan untuk dapat mengerjakan tugas-tugasnya dengan lebih cepat. Pandangan ini akan diperkuat oleh adanya kebijakan perusahaan yang lebih menghargai pemenuhan target produksi tepat waktu dibanding kesehatan dan keselamatan kerja, sebagaimana terjadi pada PT. MAT. Hal ini didukung oleh hasil analisis kualitatif dari diskusi yang menyatakan bahwa perusahaan memberikan penghargaan berupa bonus bagi karyawan bila target produksi dapat tercapai tepat waktu dan tidak memberikan penghargaan apa pun terkait dengan cara kerja yang aman. Iklim kerja perusahaan yang tidak mendukung prinsip kesehatan dan keselamatan kerja ini pada gilirannya membuat karyawan tidak memiliki sikap yang tepat terhadap penerapan penggunaan APD dalam bekerja, yaitu menganggap penggunaan APD lebih banyak menimbulkan gangguan dalam bekerja dibanding memberikan perlindungan bagi karyawan selama bekerja.

Penelitian ini melibatkan dua kelompok karyawan, yaitu mereka yang sudah pernah mengalami kecelakaan kerja dan mereka yang belum pernah mengalami kecelakaan kerja. Penelitian membuktikan bahwa karyawan yang pernah mengalami kecelakaan kerja akan bersikap negatif saat terjadi pembicaraan terkait dengan keselamatan kerja (Mearns, Flin, Gordon, dan Fleming, dalam Barling \& Frone, 2004), termasuk saat membahas penggunaan APD. Hal inilah yang diduga juga menyebabkan perubahan sikap karyawan menjadi lebih negatif terhadap penggunaan APD. Tingginya tingkat kecelakaan kerja di PT. MAT, sebagaimana digambarkan salah satu subjek dalam diskusi bahwa hampir setiap hari terjadi kecelakaan kerja tertusuk jarum, tampaknya membuat karyawan menganggap kecelakaan tersebut sebagai hal yang biasa terjadi sehingga tidak selalu melaporkannya pada atasan untuk kemudian dilakukan pencatatan. Hal ini menyebabkan beberapa subjek yang terlibat dalam penelitian sebagai karyawan yang belum pernah mengalami kecelakaan ternyata pada saat diskusi diketahui bahwa ia pernah mengalami kecelakaan kerja, yaitu tertusuk jarum. Kondisi ini menyebabkan komposisi jumlah subjek yang pernah mengalami kecelakaan menjadi lebih besar dibanding subjek yang belum pernah mengalami kecelakaan. Ketidakseimbangan komposisi ini semakin memperkuat kecenderungan sikap negatif subjek terhadap topik penggunaan APD yang dibahas dalam penelitian ini. 
Diskusi terstruktur diharapkan bukan hanya sebatas pada membicarakan bagaimana kecelakaan kerja dapat terjadi, namun juga perlu menekankan pentingnya penggunaan APD, terutama untuk mengatasi adanya kemungkinan seorang karyawan bekerja dalam keadaan yang digambarkan oleh Treloar, dkk. (1996) sebagai mindlessness maupun automatic pilot, yaitu suatu kondisi dimana seseorang bekerja dengan menjalankan suatu prosedur tertentu namun tidak berkonsentrasi pada apa yang dia lakukan. Sistem dan kondisi kerja yang menyebabkan karyawan harus bekerja dalam keadaan lelah, stres, dan jeda waktu istirahat yang pendek (quick shift) dapat menyebabkan ia bekerja dalam kondisi mindlessness atau automatic pilot (Treloar, dkk., 1996). Hasil analisis kualitatif menunjukkan bahwa hal ini kurang mendapat perhatian dari fasilitator diskusi. Subjek hanya diajak berdiskusi sampai pada kesimpulan bahwa untuk menghindari kecelakaan kerja, karyawan harus bekerja dengan lebih hati-hati dan berkonsentrasi dan tidak menyentuh pada kesimpulan bahwa penggunaan APD dapat meningkatkan keamanan karyawan bila suatu saat ia bekerja dalam kondisi mindlessness. Menilik pada teori motivasi perlindungan (Protection Motivation Theory/ PMT), penting untuk diperhatikan dalam diskusi ini, fasilitator berusaha untuk meningkatkan efikasi diri subjek terkait dengan kemampuannya untuk dapat menjalankan tugas yang diminta, yaitu menggunakan APD secara rutin selama bekerja. Hal ini didukung penelitian yang menunjukkan bahwa efikasi diri menjadi motivator utama seseorang dalam melakukan perubahan menuju perilaku kerja yang aman dan sehat (Melamed, Rabinowitz, Feiner, Weisberg, \& Ribak, 1996).

Penelitian mengenai diskusi terstruktur dilakukan oleh Stave, Tőrner, dan Eklőf
(2007) terbukti meningkatkan aktivitas terkait dengan kesehatan dan keselamatan kerja, serta menurunkan stres kerja dan penerimaan risiko. Penelitian tersebut menggunakan pendekatan longitudinal, yaitu dilaksanakan selama 15 bulan dengan pertemuan rutin kelompok dilakukan enam kali dengan jarak antar pertemuan sekitar 1 bulan. Stave, Törner, dan Eklöf (2007) melakukan pelatihan khusus bagi fasilitator yang terlibat dalam penelitiannya selama dua hari.

Pada penelitian ini, peneliti tidak cukup memberikan pemahaman kepada fasilitator mengenai tujuan dari penelitian, alur diskusi yang diharapkan, dan peran mereka sebagai seorang fasilitator. Hal ini terjadi dikarenakan adanya keterbatasan waktu mengingat tingkat kesibukan fasilitator yang tinggi. Pemahaman yang tidak memadai ini diperkirakan dapat mempengaruhi hasil eksperimen, terutama pada proses diskusi yang menunjukkan bahwa alur diskusi tidak sesuai dengan yang diharapkan oleh peneliti.

Hasil analisis kedua adalah tidak terdapat perbedaan sikap terhadap penggunaan APD antara ketiga kelompok, yaitu KE1, KE2, dan KK. Kondisi ini diduga terkait dengan dilibatkannya karyawan yang pernah mengalami kecelakaan kerja dalam penelitian ini. Pada ketiga kelompok terdapat setidaknya $50 \%$ subjek yang pernah mengalami kecelakaan kerja. Sebagaimana dijelaskan sebelumnya, bahwa karyawan dengan pengalaman kecelakaan kerja memiliki kecenderungan untuk bersikap negatif terhadap pembicaraan terkait dengan kesehatan dan keselamatan kerja. Sedikit perbedaan yang ada adalah bahwa pada kelompok kontrol, subjek hanya ditugaskan untuk mengisi skala, maka perubahan sikap tidaklah signifikan. Namun pada kelompok eksperimen dengan intensitas pembicaraan mengenai penggunaan APD yang lebih 
tinggi, melalui pemberian informasi maupun diskusi terstruktur, menyebabkan perubahan sikap menjadi lebih kuat menjadi semakin megatif.

Hal lain yang diduga menjadi penyebab tidak adanya perbedaan antara KE1 dan KE2 adalah lemahnya pengaruh pemberian informasi terhadap perubahan sikap terhadap penggunaan APD sehingga tidak dapat menciptakan perbedaan. Pemberian informasi dalam penelitian ini mengadopsi metode academic detailing sebagaimana yang digunakan dalam penelitian Mukti, dkk. (2000). Pada penelitian tersebut, academic detailing dilaksanakan melalui dua kali wawancara secara personal kepada setiap subjek yang dilibatkan. Hal ini memungkinkan adanya pemahaman yang lebih mendalam terhadap informasi yang diberikan bila dibandingkan dengan pemberian informasi secara klasikal. Pada penelitian ini, wawancara secara personal tidak dapat dilakukan dengan pertimbangan waktu dan tenaga yang tersedia. Selain itu, dalam penelitiannya, Mukti, dkk (2000) menempelkan poster dan stiker yang berisi gambar dan materi yang disampaikan dalam wawancara untuk memperkuat efek program. Pada penelitian ini, penempelan poster tidak dapat dilakukan mengingat subjek KE1 dan KE2 bekerja pada lokasi yang sama. Hal ini dilakukan supaya efek pemberian informasi dapat dikontrol hanya terjadi pada KE1 saja. Kedua faktor inilah yang mungkin menyebabkan lemahnya pengaruh pemberian informasi pada sikap terhadap penggunaan APD yang pada gilirannya menyebabkan hipotesis yang dijukan oleh peneliti ditolak.

Tidak adanya perbedaan sikap terhadap penggunaan APD pada KE1 dan KE2 dapat pula dikarenakan alokasi waktu dalam pelaksanaan intervensi yang tidak tepat. Alokasi waktu intervensi antara KE1 dan KE2 seharusnya sama, tanpa mempedulikan intervensi yang diberikan. Namun dalam penelitian ini, peneliti memberikan alokasi waktu yang sama antara pemberian informasi dan diskusi, sehingga lama waktu intervensi pada KE1 hampir dua kali lipat lama waktu intervensi pada KE2.

Selain itu, peneliti juga menyoroti adanya kemungkinan pemilihan tempat penelitian, yaitu PT. MAT, yang kurang mendukung penelitian ini. Perusahaan ini memiliki tingkat kecelakaan yang cukup tinggi, namun didominasi oleh kecelakaan yang bersifat minor, seperti tertusuk jarum dan terkena gunting. Tingginya frekuensi kecelakaan minor dan ketiadaan kecelakaan yang bersifat mayor, yaitu kecelakaan yang menyebabkan cacat permanen atau bahkan hilangnya nyawa dari penderita diduga dapat menyebabkan karyawan memandang bahwa kecelakaan yang terjadi di tempat kerjanya adalah suatu hal yang biasa dan normal terjadi. Pandangan ini pada gilirannya akan menyebabkan karyawan tidak memahami pentingnya tindakan pencegahan kecelakaan, salah satunya melalui penggunaan APD dalam bekerja.

Terdapat keterbatasan dalam penelitian ini terkait dengan proses pemberian pelatihan, motivasi peserta, tempat pelaksanaan pelatihan dan waktu pelatihan. Hal ini senada dengan yang diungkapkan oleh Setiono dan Pramadi (dalam Mettasari, 2009) tentang faktor yang mempengaruhi keberhasilan dari suatu pelatihan. Pada penelitian ini diberikan dua bentuk intervensi. KE1 mendapatkan informasi dan diikuti dengan diskusi terstruktur, sedangkan KE2 hanya mendapatkan diskusi terstruktur saja.

Berdasarkan hasil analisis statistik tidak terdapat perbedaan hasil antara kedua kelompok. Selain itu, diskusi dilaksanakan pada dua kelompok secara terpisah dan 
difasilitasi oleh dua orang fasilitator. Hal ini dapat memunculkan adanya perbedaan dalam proses diskusi yang ada, meskipun hasil analisis statistik juga menunjukkan tidak terdapat perbedaan antara kedua kelompok diskusi. Hal ini mungkin dikarenakan peneliti telah berusaha mengatasi kemungkinan munculnya perbedaan hasil diskusi akibat perbedaan fasilitator ini dengan melibatkan kedua fasilitator pada masing-masing kelompok sebagaimana dilakukan oleh Stave, Tőrner, dan Eklőf (2007) dalam penelitiannya.

Pelatihan yang dilaksanakan pada hari libur, yaitu hari Minggu berpotensi dapat menurunkan motivasi dari subjek penelitian yang harus menyempatkan diri untuk datang ke tempat pelatihan atas perintah perusahaan. Selain itu, kondisi karyawan yang cukup lelah setelah lembur pada hari sebelumnya dapat pula menurunkan motivasi subjek penelitian. Meski secara umum, hasil observasi menunjukkan antusiasme subjek yang cukup tinggi selama proses pemberian informasi maupun di saat diskusi kelompok.

Pelatihan dilaksanakan dalam ruang pertemuan di gedung PT. MAT. Subjek menyatakan ruangan sejuk dan cukup nyaman dibanding kondisi di luar ruangan, terutama pada saat semua mesin dinyalakan, karena dalam ruangan tersebut dipasang pendingin ruangan. Keterbatasan ruangan cukup terasa pada saat diskusi dimulai. Akibat ketiadaan ruangan, kedua kelompok melaksanakan diskusi di ruang yang sama dan hanya dipisahkan oleh jarak kurang lebih 2 meter. Hal ini berpotensi mengganggu konsentrasi subjek dalam melakukan diskusi. Salah satu observer pun menyatakan bahwa subjek sering melihat ke arah kelompok lain selama diskusi berlangsung.
Untuk penelitian selanjutnya ada baiknya dilakukan pemisahan geografis yang lebih tegas dalam hal lokasi kerja antara subjek $\mathrm{KE}$ dan $\mathrm{KK}$, maupun antar $\mathrm{KE}$ dengan intervensi yang berbeda sehingga memungkinkan peneliti memberikan intervensi secara lebih komprehensif, seperti melakukan penempelan poster sebagai penguat dalam pelaksanaan academic detailing. Ada baiknya menghindari pelaksanaan pelatihan pada hari libur kerja maupun hari setelah karyawan melaksanakan lembur pada hari kerja sebelumnya untuk mencegah penurunan motivasi subjek dalam mengikuti pelatihan.

Pemilihan perusahaan sebagai tempat penelitian yang memiliki catatan kecelakaan yang tinggi dengan tipe kecelakaan mayor lebih disarankan agar lebih memungkinkan untuk melihat akibat dari perilaku tidak aman dalam bekerja dan menyadari pentingnya keselamatan kerja maupun pencegahan kecelakaan menggunakan APD. Penambahan materi terkait dengan mindlessness dalam informasi dapat diberikan guna menekankan pentingnya penggunaan APD yang dapat melindungi karyawan dari kecelakaan kerja saat berada dalam kondisi kehilangan konsentrasi maupun kurang berhati-hati.

\section{KESIMPULAN}

Berdasarkan hasil analisis kuantitatif dapat disimpulkan bahwa terdapat perbedaan sikap karyawan terhadap penggunaan APD sebelum dan segera setelah mendapat intervensi. Namun arah perubahan ini berkebalikan dengan apa yang diharapkan peneliti dalam hipotesis. Faktor-faktor yang diduga mempengaruhi hasil penelitian ini, antara lain iklim perusahaan yang tidak menempatkan kesehatan dan keselamatan kerja sebagai prioritas dalam 
proses produksi, dilibatkannya karyawan dengan pengalaman kecelakaan kerja yang diduga memiliki sikap yang negatif terhadap pembicaraan terkait dengan kesehatan dan keselamatan kerja, kurang sesuainya alur diskusi yang dilaksanakan dengan alur diskusi yang diharapkan oleh peneliti dalam modul penelitian.

Selain itu, hasil analisis juga menunjukkan bahwa tidak terdapat perbedaan sikap karyawan antara KE1, KE2, maupun KK baik sebelum, segera setelah, dan 3 minggu setelah intervensi diberikan. Hal ini terutama diduga muncul karena ketiga kelompok memiliki karakteristik yang sama, yaitu melibatkan karyawan dengan pengalaman kecelakaan kerja yang cenderung bersikap negatif terhadap topik penelitian ini. Tidak terdapatnya perbedaan antara KE1 dan KE2 diduga disebabkan oleh lemahnya pengaruh pemberian informasi pada perubahan sikap karyawan yang dikarenakan terdapat beberapa konsep dalam academic detailing tidak dapat dilaksanakan dalam penelitian ini, seperti wawancara secara personal serta penempelan poster dan stiker yang berfungsi mengingatkan subjek penelitian mengenai apa yang telah mereka diskusikan selama wawancara.

\section{DAFTAR PUSTAKA}

Adebiyi, K. A., \& Charles-Owaba, O. E. (1990). Towards setting a sustainable manufacturing safety programme in Nigeria. Disaster Prevention and Management, 18, 388-396. DOI: 10.1108/ 09653560910984447

Aron, A. \& Aron E. N. (2003). Statistics for psychology. New Jersey, NJ: Pearson Education, Inc.
Barling, J. \& Frone, M. R. (2004). The psychology of workplace safety. Washington, DC: American Psychological Association

Berry, L. M. (1998). Psychology at work: An introduction to industrial and organizational psychology. Singapura: McGraw-Hill Companies, Inc.

Calvin, S., \& Joseph, B. (2006). Occupational related accidents in selected garment industries in Bangalore City. Indian Journal of Community Medicine, 31, 150-152.

Cook, T. D. \& Campbell, D. T. (1979). Quasi-experimentation: Design \& analysis issues for field settings. Boston: Houghton Mifflin Company.

Diekhoff, G. (1992). Statistics for the Social and Behavioral Sciences: Univariate, Bivariate, Multivariate. Dubuque, Iowa: Wm. C. Brown Publisher

Ewigman, B. G., Kivlahan, C. H., Hosokawa, M. C., \& Horman, D. (1990). Efficacy of an intervention to promote use of hearing protection devices by firefighters. Public Health Reports, 105(1), 5359.

Geller, E. S. (2001). The psychology of safety handbook. Boca Raton, Florida: Lewis Publishers.

Kristensen, K. B., Pedersen, D. M., \& Williams, R. N. (2001). Profiling Religious Maturity: The Relationship of Religious Attitude Components to Religious Orientations. Journal for The Scientific Study of Religion, 40, 75- 
86. DOI: 10.1111/0021-8294.00039

Melamed, S., Rabinowitz, S., Feiner, M., Weisberg, E., \& J, R. (1996). Usefulness of the protection motivation theory in explaining protection device use among male industrial workers. Health Psychology, 15, 209-215. DOI: 10.1037/0278-6133.15.3.209

Mettasari, S. (2009). Efektivitas pelatihan asertivitas untuk meningkatkan keterampilan komunikasi interpersonal. Tesis (Tidak dipublikasikan). Yogyakarta: Universitas Gadjah Mada.

Mukti, A. G., Treloar, C., Wimbarti, S., Asdie, A. H., D'Este, K., Higginbotham, N., \& Heller, R. (2000). A Universal Precautions Education Intervention for Health Workers in Sardjito and PKU Hospital Indonesia. The Southeast Asian Journal of Tropical Medicine and Public Health, 31, 405-411.

Olson, J. M., \& Maio, G. R. (2003). Attitudes in social behavior . In T. Millon, \& M. J. Lerner, Handbook of psychology: Personality and social psychology (pp. 299-326). New Jersey: John Wiley \& Sons, Inc.

Omrod, J. E. (2003). Human learning. New Jersey, NJ: Pearson Education Inc.

Petty, R. E., Wheeler, S. C., \& Tormala, Z. L. (2003). Persuasion and attitude change. In T. Millon, \& M. J. Lerner, Handbook of psychology: Personality and social psychology (pp. 353-382). New Jersey, NJ: John Wiley \& Sons, Inc.
Riyadina, W. (2007). Kecelakaan kerja dan cedera yang dialami oleh pekerja industri di kawasan industri Pulo Gadung Jakarta. Makara Kesehatan, 11, 25-31.

Robbins, S. P. (2005). Organizational behavior. New Jersey, NJ: Pearson Education, Inc.

Schweiger, D. M., \& DeNisi, A. S. (1991). Communication with employees following a merger: A longitudinal field experiment. Academy of Management Journal, 34, 110-135. DOI: $10.2307 / 256304$

Shadish, W. R., Cook, T. D., \& Campbell, D. T. (2002). Experimental and quasi-experimental designs for generalized causal inference. Boston, MA: Houghton Mifflin Company.

Smith, M. J., Karsh, B.-T., Carayon, P., \& Conway, F. T. (2003). Controlling occupational safety and health hazards. In J. C. Quick, \& L. E. Tetrick, Handbook of occupational health pschology (pp. 35-68). Washington, DC: American Psychological Association.

Stave, C. (2005). Safety as a process: From risk perception to safety activity. Göteborg, Sweden: Chalmers University of Technology.

Stave, C., Törner, M., \& Eklőf, M. (2007). An intervention method for occupational safety in farming evaluation of the effect and process. Applied Ergonomics, 38, 357-368. 
Treloar, C. J., Higginbotham, N., Malcolm, J., Sutherland, D., \& Berenger, S. (1996). An 'academic detailing' intervention to decrease exposure to HIV infection among health-care workers. Journal of Health Psychology, 4, 455-468. DOI: $10.1177 / 13591053960010040$ 